\title{
An overview of the Jordanian oil shale: its chemical and geologic characteristics, exploration, reserves and feasibility for oil and cement production
}

\author{
Ziad Salem H. Abu-Hamatteh \\ Water Resources and Environmental Management \\ Department, Faculty of Agricultural Technology, \\ Al-Balqa' Applied University, Jordan
}

\author{
Ali F. Al-Shawabkeh \\ Basic Sciences Department \\ Faculty of Engineering Technology, \\ Al-Balqa' Applied University, Jordan
}

\begin{abstract}
Oil shale is the most abundant fossil energy resource discovered in Jordan, ranking third after the USA and Brazil in terms of oil shale reserves. This asset is considered to be Jordan's most extensive domestic fossil-fuel source. The identified reserves of this oil shale are huge and sufficient to satisfy the national energy needs for hundreds of years. Numerous geologic studies have shown that the country contains several oil shale deposits. These deposits are regarded as the richest in organic bituminous marl and limestone that occur at shallow depth. Jordanian oil shale is generally of a good quality, with relatively low ash and moisture contents, a gross calorific value of $7.5 \mathrm{MJ} / \mathrm{kg}$, and an oil yield of 8 to $12 \%$. The spent shale has residual carbon content that may be burned to produce further energy, and ash that can be used for cement and building materials. The current study summarizes the results of the former feasibility studies and discuses the scope of future usage of Jordanian oil shale. The value of this oil shale and its associated products is highlighted herein.
\end{abstract}

Key words: oil shale, ash, energy, El-Lajjun, resources, Jordan

\section{Introduction}

The situation in the area of global energy provides sufficient reasons to believe that in the near future, conventional fossil fuel will no longer be available as a source of sustainable energy in the quantities known today. Thus oil shale is considered to be one of the promising options to substitute conventionallyderived fuels in the future. If the organic material contained in the shale were to be converted to oil, the quantities would exceed by far all known conventional oil reserves. Oil shale resources of the world are abundant and are considered to be 
one of the largest fossil energy reserves in the world next to coal and tar sands. It is found in nearly 100 major deposits in 27 countries worldwide (Dinneen 1970; Allred 1982; Speight 1990; Dehong and Jialin 1991; Abu-Hamatteh et al. 2008).

Oil shale is found globally in rocks of Cambrian to Tertiary age, for instance in Australia, Brazil, China, Estonia, Germany, Israel, Jordan, Russia, Thailand; the most important deposits occur in the USA (Altun 2006). Production of oil shale is limited to a few countries, with Estonia being the dominant producer. The largest known oil shale deposits in the world are in the Green River Formation ranging, from 2.4 to 2.9 trillion $\mathrm{m}^{3}$ (Tissot and Welte 1978; Speight 1990). However, the economics of shale oil production have remained persistently behind those of conventional oil. Oil shale contains about $25 \%$ solid organic material, mostly kerogen and some bitumen (Altun 2006; Ots 2007). It was discovered that the production steps from oil shale to oil could be speeded up by heating in the absence of air, applying a pyrolysis process, with temperatures in the range of $500^{\circ} \mathrm{C}$.

Jordan's oil shale is considered to be the most extensive domestic fossil fuel source throughout the 21st century and beyond, since Jordan ranks third in the world for oil shale reserves (Jaber et al. 1997; Jaber et al. 2001). The identified reserves of this oil shale are huge (50-70 billion metric tons) and sufficient to satisfy the national energy needs for hundreds of years. One ton of shale rock will typically produce one barrel of shale oil compound. The resulting spent shale has potential market value in various areas. In addition, the large heat value produced can be used as a source for heating new shale rock entering the retort. The spent shale has a residual carbon content that may be burnt to produce further energy, and ash that can be used for cement and building materials. Table 1 shows the Fisher Assay values for some oil shale deposits. Recent oil shale resource figures from the U.S. Department of Energy are: U.S. $(72.0 \%$ of the world supply of oil shale), Brazil (5.4\%), Jordan (4.2\%), Morocco (3.5\%), Australia (2.1\%), China (1.5\%) and Estonia (1.1\%) (Abu-Hamatteh et al. 2008).

Table 1

Fisher Assay values for some worldwide oil shale deposits

\begin{tabular}{|c|c|c|c|c|c|}
\hline Oil shale deposits & $\begin{array}{c}\text { Moisture } \\
\text { content (wt\%) }\end{array}$ & Water & Oil & Residue & $\begin{array}{c}\text { Gas and } \\
\text { losses }\end{array}$ \\
\hline $\begin{array}{c}\text { Kvarntrop } \\
\text { (Sweden) }\end{array}$ & 2.0 & & 5.7 & 87.2 & 5.1 \\
\hline Kukersite (Estonia) & Dry & 1.9 & 22.0 & 70.5 & 5.6 \\
\hline Green River (USA) & Dry & 1.4 & 10.4 & 85.7 & 2.5 \\
\hline Irati (Brazil) & 4.6 & 1.2 & 6.9 & 83.6 & 3.7 \\
\hline Maoming (China) & 5.0 & 3.2 & 7.3 & 80.6 & 3.9 \\
\hline El Lajjun (Jordan) & 4.0 & 1.4 & 10.1 & 80.8 & 3.7 \\
\hline
\end{tabular}




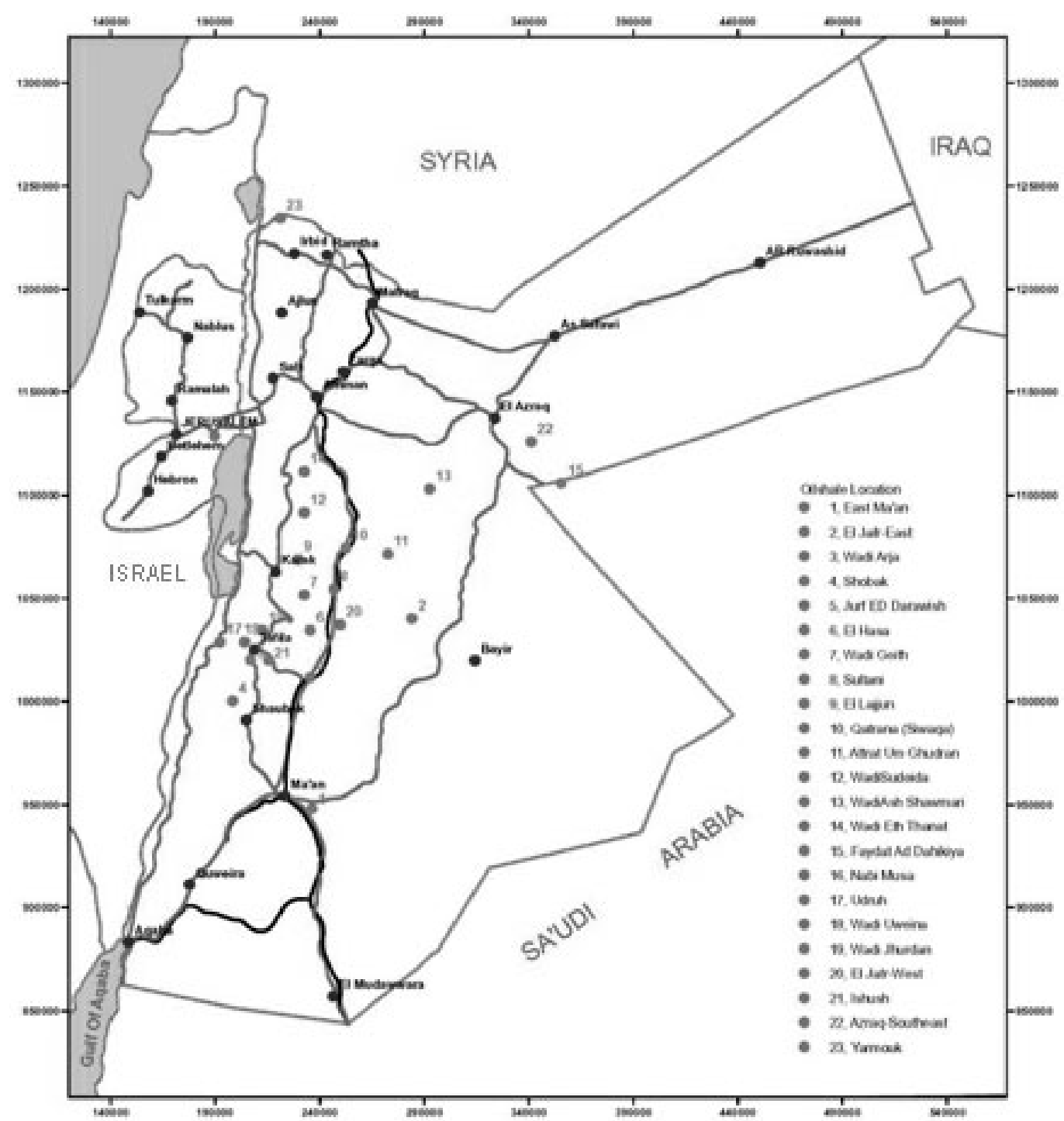

Fig. 1

Oil shale occurrences in Jordan

\section{Jordan's oil shale resources}

Jordan (Easting: minimum $35^{\circ} 50^{\prime} /$ maximum $39^{\circ} 12^{\prime}$; Northing: minimum $29^{\circ}$ $15^{\prime} /$ maximum $39^{\circ} 12^{\prime}$ ) is favorably situated between the Precambrian outcrop belt and the rich oil-producing area of the Persian Gulf coastal geo-syncline, making it a prime prospective frontier area for oil and gas deposits (Fig. 1). There is also 
an abundance of surface indications of hydrocarbons in the form of seeps, asphalt impregnation and near-surface deposits of rich oil shale. At present, Jordan meets its oil needs from Saudi Arabia, Iraq, Kuwait and United Arab Emirates. Jordan has only one small oil field (Hamza) in the eastern part of the nation. The Risha gas field is the only field that produces gas in Jordan, being also located in the eastern part of Jordan. The proven recoverable reserves of natural gas are about 288 million $\mathrm{m}^{3}$. This reserve provides an output of the gas field of one million $\mathrm{m}^{3} /$ day. The Al-Risha Power Station supplies Jordan with $10 \%$ of its electricity, using natural gas. The electricity sector preserved a sustainable growth of $15 \%$ on average, covering $99 \%$ of the country. Currently the total installed capacity stands at 1,636 MW generated by eight plants. These plants are fired by a combination of natural gas that is imported from Egypt, heavy fuel oil and diesel (NEPCO 2007). Apart from oil and gas possibilities, Jordan has a number of energy potential resources which could act as an energy base in the next decade and beyond (Mustafa et al. 1993). Table 2 provides a summary of the potential new and renewable energy resources in Jordan (Jaber et al. 1997; Jaber et al. 2001; Abu-Hamatteh et al. 2008).

Large deposits of oil shale are widely distributed all over Jordan (Fig. 1). Geologic surveys have confirmed the existence of oil shale reserves that cover more than $60 \%$ of Jordan's surface, and some of the major oil shale deposits are underlain by phosphate beds. Huge proven and exploitable near-surface reserves are estimated to be more than 50 billion metric tons with extractable crude oil equivalent to about 8 billion $\mathrm{m}^{3}$ of oil.

Table 2

Estimated potential of the renewable energy resources in Jordan

\begin{tabular}{|c|c|c|}
\hline Oil shale & Geological reserves & 40 billion tons \\
\hline Tar sands & Geological reserves & 40 million tons \\
\hline Uranium & $\begin{array}{c}\text { Uranium to phosphate ratio } \\
\text { Uranium reserves }\end{array}$ & $\begin{array}{c}80-160 \mathrm{PPM} \\
8-16 \text { thousand tons }\end{array}$ \\
\hline Solar & Average $5.5 \mathrm{kWh} / \mathrm{m}^{2}$ iday & Potential 1.3 million MW \\
\hline Wind & $5-8 \mathrm{~m} / \mathrm{s}$ average wind speed & More than $1000 \mathrm{MW}$ \\
\hline Bio gas & - & More than $50 \mathrm{MW}$ \\
\hline Hydro & When constructing RSDS canal & $600 \mathrm{MW}$ \\
\hline Geothermal & Under investigation & \\
& &
\end{tabular}


Geologic studies have shown that over $60 \%$ of the country contains oil shale deposits. There are more than 25 surface and near-surface occurrences of oil shale in Jordan, eight of which have been studied in detail (Table 3). These major surface deposits of commercial-scale interest are located about $100 \mathrm{~km}$ south of

Table 3

Characteristics of the major oil shale reserves in Jordan

\begin{tabular}{|c|c|c|c|c|c|c|}
\hline $\begin{array}{c}\text { Location of } \\
\text { the deposit }\end{array}$ & $\begin{array}{c}\text { Horizontal } \\
\text { extent } \\
\left(106 \mathrm{~m}^{2}\right)\end{array}$ & $\begin{array}{c}\text { Mean } \\
\text { thickness } \\
(\mathrm{m})\end{array}$ & $\begin{array}{c}\text { Overburden } \\
\text { thickness } \\
(\mathrm{m})\end{array}$ & $\begin{array}{c}\text { Stripping } \\
\text { ratio }\end{array}$ & $\begin{array}{c}\text { Average oil } \\
\text { content } \\
(\mathrm{Wt} \%)\end{array}$ & $\begin{array}{c}\text { Proven } \\
\text { reserve } \\
(106 \text { tons })\end{array}$ \\
\hline Wadi Maghar & 29 & 40 & 41 & 1.02 & 6.8 & 31,600 \\
\hline $\begin{array}{c}\text { Wadi Thamad } \\
150\end{array}$ & 136 & 60 & 0.44 & 10 & 11,400 \\
\hline $\begin{array}{c}\text { Attarat Um } \\
\text { Gadran }\end{array}$ & 226 & 45 & 53 & 1.17 & 11 & 11,300 \\
\hline $\begin{array}{c}\text { Jurf Ed } \\
\text { Darawish }\end{array}$ & 150 & 64 & 48 & 0.75 & 6 & 8,506 \\
\hline $\begin{array}{c}\text { El-Lajiun } \\
\text { Sultani }\end{array}$ & 20 & 30 & 26 & 0.87 & 10.5 & 1,196 \\
\hline Khan Zabib & - & - & - & - & 7 & - \\
\hline Siwaga & - & - & - & - & 7 & - \\
\hline
\end{tabular}

Amman (Fig. 1 and Table 3). These deposits are regarded as the richest organic bituminous marl and limestone that occur at shallow depth (Jaber et al. 2001).

Jordan's oil shale is generally of a good quality, with relatively low ash and moisture content. The gross calorific value ranges between 6 and $8 \mathrm{MJ} / \mathrm{kg}$ and average oil yield is about $8-12 \%$, similar to values from western Colorado (USA) shale. Jordan's oil shale is a kerogen-rich bituminous argillaceous limestone that was deposited in a shallow marine euxinic environment, mostly during the Maastrichtian and Paleocene. The kerogen in this limestone was formed by fossil remains of plants and plankton that accumulated in prehistoric seas and lakes that covered most of Jordan some 80 million years ago, during the Upper Cretaceous. It is believed that plaktonic organisms such as algae are the main source materials. Table 4 shows the overall characteristics of the Jordanian oil shale in comparison with oil shale from other localities in the world (AbuHamatteh et al. 2008). 
Table 4

Characteristics of Jordanian oil shale. Other oil shale are given for comparison (\% all reported analysis by weight average)

\begin{tabular}{|c|c|c|c|c|c|c|c|}
\hline & Jordan & Morocco & Estonia & China & Europe & USA & Brazil \\
\hline $\mathrm{CV}(\mathrm{kcal} / \mathrm{kg})$ & 1800 & 1100 & 2000 & 1500 & 1986 & 1800 & 1340 \\
& & & & & & & \\
\hline Oil content (\%) & $8-12$ & 7 & 20 & 7 & 13 & 9.7 & 7 \\
\hline Organic carbon (\%) & 19 & 11 & 19 & 12 & 20 & 17.3 & 2.6 \\
\hline $\mathrm{H}_{2}(\%)$ & 2 & 2 & 2.5 & 2 & 2.7 & 1.7 & 1.9 \\
\hline $\mathrm{O}_{2}(\%)$ & 1.8 & 9.6 & 7.5 & 7 & 11.5 & 2.1 & 2.7 \\
\hline $\mathrm{N}_{2}(\%)$ & 0.34 & - & 0.2 & 0.38 & 0.2 & 1.3 & 0.6 \\
\hline $\mathrm{S}(\%)$ & 3.2 & 1.2 & 1.55 & 0.3 & 6 & 0.65 & 0.6 \\
\hline $\mathrm{H}_{2} \mathrm{O}(\%)$ & 2.5 & 10 & 11.5 & 13 & 12.7 & 0.7 & 5.3 \\
\hline $\mathrm{Ash}(\%)$ & 55 & 64 & 44 & 71 & 45 & 68.3 & 79.8 \\
\hline
\end{tabular}

British geologists investigated the oil shale of the general region after World War One, taking samples and carrying out retorting tests. Records from the outcrop of the Shallaleh deposits have indicated that villagers have used the shale for many years to heat water and to lime their homes and wells. Preliminary studies of Jordan oil shale began in the late 1960s but no action was taken at that time because the level of oil prices was far too low for a viable oil shale development program (Speers 1969). However, following the oil crises of the mid-1970s and 1980s, the Government of Jordan (GOJ) began conducting extensive studies for the exploitation of oil shale reserves, mainly of two deposits, namely El-Lajjun and Sultani (Fig. 2).

Detailed surveys were carried out by obtaining cores and performing laboratory work to determine proven geologic reserves, quality, oil content and calorific value (Abu Ajamieh 1980). The GOJ has also conducted many feasibility studies on oil shale that have led to its assessment and that of the suitability of the state-of-the-art technologies that have been developed so far, and have reached a mature stage of commercial development.

The geologic conditions, such as the thickness and the structural setting as well as the chemical and mineralogical composition, are favorable for open-pit mining. All these factors, together with the low mining and infrastructure costs, 
Fig. 2

Proportion of the Jordanian oil shale reserves

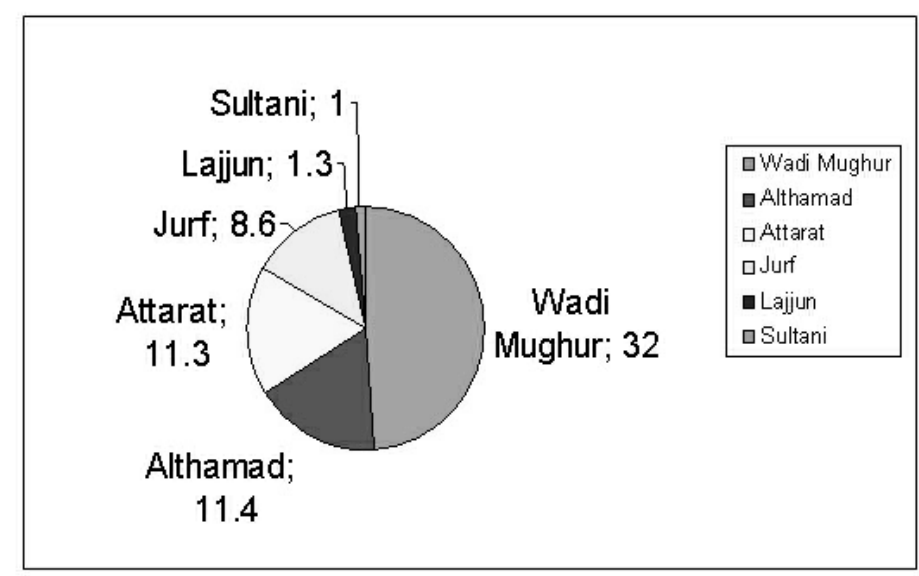

render the deposit quite suitable for industrial utilization. The production of oil and electricity using oil shale could be a viable option even at today's oil prices.

\section{Geology of oil shale in Jordan}

Geologically the oil shale belongs to the Upper Cretaceous and Lower Tertiary formations. Oil shale deposits were discovered in the central part of the country and are classified as shallow and near-surface deposits. Other deeper lying deposits which are located in the north and east part of Jordan are exploitable only by underground mining operations.

The Jordanian oil shale is bituminous, and to varying degrees brown, grey or dark grey calcareous marl with a typical bluish light-grey color when weathered (Quennell 1951; Powell et al. 1975; Abu Ajamieh 1980; Annual Report 2007). Oil shale is defined as a sedimentary rock; its solid organic content may be altered by thermal maturation, converted by retorting which forces the decomposition of kerogen and releases hydrocarbons as liquid oil-like hydrocarbons when exposed to temperatures of up to $500{ }^{\circ} \mathrm{C}$. Oil shale can be burnt directly when crushed to about $5 \mathrm{~mm}$ grain size in modern fluidized bed technology.

Thickly-bedded or concretionary limestone, sometimes associated with dolomite and chert, is interbedded in the oil shale sequence; a phosphate layer usually occurs beneath the oil shale deposits. Major surface deposits of commercial-scale interest are located about $100 \mathrm{~km}$ south of Amman, known as the El-Lajjun and Sultani deposits. These deposits are regarded as the richest organic bituminous marl and limestone that occur at shallow depth (Fig. 1). 
Previous work in Jordan

There is evidence that early settlers in Jordan exploited oil shale from outcrops to heat water and to lime their homes and wells. Oil shale occurrences east of the Jordan River were documented after World War I. Geologic investigations were conducted at El-Lajjun by the German Geological Mission (Lurgi 1988), and the geology of the general oil shale area was undertaken by Bender $(1968 ; 1974)$, who also conducted limited retorting tests. Preliminary studies resumed in the late 1960s, and these became serious after oil prices rose sharply in the 1980s. The most extensive studies have been of the El-Lajjun and Sultani resources, because these are favorably located and amenable to open-cast mining (Abu Ajamieh 1980; Annual Report 2007). The investigated applications included both retorting for oil production and direct combustion for generation of electric power. Many of the studies were conducted in cooperation with foreign entities, some of which were interested in commercial development projects. The more relevant studies are summarized below.

Lurgi-Klockner: In 1980, Jordan's Natural Resources Authority commissioned the Lurgi-Klockner consortium of West Germany to study two development options. The first option was a retorting complex that would use the LurgiRuhrgas retorting process to produce $7950 \mathrm{~m}^{3} /$ day of liquid fuel. The second was a complex to generate $300 \mathrm{MW}$ of electricity with Lurgi circulating fluidized bed combustion (CFBC) units. The studies were completed in 1982. Both the retorting plant and the power plant were regarded as practical and profitable. The retorting option was recommended because it was more cost effective. In 1986, Lurgi-Klockner studied the feasibility of a complex that produced $7950 \mathrm{~m}^{3} /$ day of upgraded shale oil and used CFBC units to make electricity for the national grid. The total investment was expected to be $\$ 1,884$ million, and shale oil was estimated to cost \$25 per barrel (Lurgi and Klockner 1986; Lurgi 1988; Lurgi and NRA 1986).

Technoprom: In 1980 the NRA commissioned the Soviet agency Technoprom Export to study the use of oil shale to fuel a conventional $300 \mathrm{MW}$ power plant. The study found the oil shale to be a suitable fuel and recommended construction of a $200 \mathrm{MW}$ demonstration plant, similar to a plant that burned Estonian oil shale. The Government preferred a smaller power plant, and the project was terminated.

SINOPEC: In 1985 the NRA engaged China Petro-Chemical International Company (SINOPEC) to test El-Lajjun oil shale in the Fushun retorts used in China's oil shale industry. Chemical tests were conducted on a half-tone sample, and 1200 tons were consumed in performance tests in China (China PIC and NRA 1986). SINOPEC submitted a proposal for a 100 ton-per-day retort, but the NRA did not proceed because of high costs and technical uncertainties.

Brown Boveri: In 1987 the Brown, Boveri \& Company Ltd. of Switzerland studied the use of Jordanian oil shale to generate electricity in conventional 
power boilers. Capital and operating costs and water requirements were estimated for three plant capacities (Brown and JEA 1987).

Lummus: In 1988, Lummus Canada Inc. burned 75 tons of Sultani oil shale in a CFBC pilot plant and studied the feasibility of several sizes of small commercial power plants (CELC Inc. \& JEA 1988).

Bechtel: In 1988 and 1989 Bechtel Inc. burned 70 tons of Sultani oil shale in a 0.85 MW CFBC pilot plant in Finland and completed preliminary feasibility studies for power plants with three feed rates (Bechtel \& JEA 1989).

$A B N-A M R O$ : In 1998 the ABN-AMRO Bank submitted a proposal on behalf of Oil Shale Energy Jordan (OSEJ), a multi-national consortium. Five oil shale plants were to be built over a 10-year period, reaching a total capacity of $1350 \mathrm{MW}$ and $239 \mathrm{~m}^{3}$ /day of diesel fuel. The plants would use UTT 3000 solid heat carrier retorts, which were developed in Russia and used commercially in Estonia. The first plant was intended to open-cast mine 12,000 tons per day of oil shale and produce $270 \mathrm{MW}$ of electricity and $477 \mathrm{~m}^{3} /$ day of diesel fuel. This plant would cost $\$ 355.2$ million in then-current dollars. The Government was asked to pay $\$ 0.045$ per $\mathrm{kWh}$ in July 1998 dollars and to buy the diesel fuel for about $\$ 120.70$ per ton, or approximately $\$ 17$ per barrel, which would have been a good deal, given the way things turned out.

There were many other programs over the years. In 1995, for example, the Japan National Oil Corporation conducted an economic evaluation of applying a novel process to the El-Lajjun oil shale (Harada 1991). In 1999 the Canadian energy company Suncor tested the processing of Jordanian oil shale in a pilot plant employing the ATP retorting technology (Taciuk 1987; SUNCOR 1999). There were also many studies of using oil shale to make a variety of products, from cement to animal feed (Mitsubishi \& NRA 1986). Based on this extensive body of work the Government has concluded that it is time to move forward and to create an oil shale industry. The eventual exploitation of Jordan's fuel resource to produce liquid fuels and/or electricity, together with chemicals and building materials, would be favored by four factors, which are:

1. High organic matter content of Jordanian oil shale;

2. Suitability of the deposits for surface mining;

3. The location - distant from population centers but with good transportation links to potential consumers (i.e. phosphate mines, potash and cement works), and most importantly

4. The unit price of crude oil.

All feasibility studies and test burns have concluded that the Jordanian oil shale burns very stably, even at loads as low as $40 \%$, low $\mathrm{SO}_{2}$ and $\mathrm{NO}_{\mathrm{x}}$ emission levels can be achieved in the CFB combustor; a high carbon burn out (99\%) can be achieved. Based on the results of combustion of 75 tons of Jordanian Sultani oil shale in Finland, Pyropower concluded that the samples of oil shale are 
acceptable fuel for an Ahlstrom Pyroflow CFB, where it burned cleanly and efficiently; a combustion efficiency in excess of $98.5 \%$ was demonstrated. Both $\mathrm{SO}_{2}$ and $\mathrm{NO}_{\mathrm{x}}$ emissions and $\mathrm{CO}$ emissions were acceptably low. The tests demonstrated that over $90 \%$ of the fuel sulfur was absorbed by the inherent calcium in the oil shale. Typical emissions $\mathrm{SO}_{2}, \mathrm{NO}_{x}$ and $\mathrm{CO}$ measured during these tests were below $20 \mathrm{ppm}$, ranging from $60-120 \mathrm{ppm}$ and below $50 \mathrm{ppm}$, respectively (Bechtel \& JEA 1989). These values will generally meet the more stringent environmental requirements. Results of the combustion test carried out on 75 tons of Sultani oil shale sampled by Lurgi concluded that:

1 . There were no upsets in the fluidizing behavior of the circulating material and/ or in plant operation;

2. Combustion of oil shale was self-sustained;

3. With a particle size $3-5 \mathrm{~mm}$ the combustion of oil shale did not pose any problems;

4. Carbon burn-off reached $98 \%$;

5. In view of the $\mathrm{CaCO}_{3}$ content of the oil shale ash it was not necessary to add limestone for desulfurization, as per the following chemical reactions:

$\mathrm{CaCO}_{3}=\mathrm{CaO}+\mathrm{CO}_{2}$

$\mathrm{CaO}+\mathrm{SO}_{2}+1 / 2 \mathrm{O}_{2}=\mathrm{CaSO}_{4}$ (calcium sulfate, resembles plaster); and

6. In view of the low combustion temperature, the $\mathrm{SO}_{2}, \mathrm{NO}_{\mathrm{x}}$ and $\mathrm{CO}$ emissions were acceptable by international standards.

\section{Oil shale extraction and results}

Solvent extraction of organic matter is one of the best-known techniques for dissolving organic matter within composite rock. Research and development activities were carried out in Jordan and investigated El-Lajjun oil shale, using a solvent mixture of $75 \%$ benzene and $25 \%$ cyclohexane by volume. This was found to be the best solvent of various organic solvents, such as toluene, benzene, cyclohexane, pentane, ethylether and ethylbenzene, to produce $73 \%$ of high yields of extracted oil in a continuous sterling tank reactor (CSTR). It was found that extraction yield from fine particles exceeded that from the coarse particles by an amount which decreased with the increase in residence time. The higher the temperature to which the oil shale is preheated (less than the boiling point of the solvent), the higher is the extraction yield for the same residence time. It was found that the effect of extraction time of yield was much longer for larger particles (diameter more than $2 \mathrm{~mm}$ ) than for smaller ones. The optimum weight of solvent used was $0.5 \mathrm{~kg}$ solvent per $\mathrm{kg}$ oil shale.

A study conducted jointly between the Natural Resources Authority (NRA) and the National Energy Research Center (NERC) used a soxhlet extractor to extract oil from the El-Lajjun oil shale samples, using different solvents to determine the best one, and the best technique based on the quality and quantity of the yield and solvent obtained. It was found that maximum oil recovery can be 
achieved $(23.37 \%$ ) by using a carbon disulfide by soxhlet type extractor (Annual Reports 2006, 2007).

Eleven organic solvents were used to extract oil shale organic matter by soxhlet extractors for an extraction duration of twenty-hour (Annual Reports 2006, 2007). These organic solvents are xylene, toluene, dichloromethane, chloroform, carbon tetrachloride, ethanol, carbon disulfide, perchloroethylene, trichloroflouromethane, petroleum spirits, and a 3:1 mixture of benzene and cyclohexane.

The soxhlet extractor is used to extract organic compounds from solids. The center chamber of the extractor contains a porous fiber glass thimble. Inside the thimble is placed the solid sample. The round bottom flask contains a volatile organic solvent, which is heated to boiling point to create enough vapor pressure to produce a steady flow of liquid drops from the condenser at the top of the soxhlet extractor. Once the solvent in the upper chamber rises above the relief arm, the solvent is returned back to the round bottom flask and the process repeats itself (Annual Report 2006, 2007).

The solvent is then removed by evaporation at room temperature. Then the sample is placed in a sand bath beneath a nitrogen evaporator in order to separate the solvents from the extracted organic matter. Organic matter was determined to be the difference between the weight of the vial with the extracted organic matter and the weight of the empty vial. The sample which was subjected to solvent extraction is removed and dried in an oven. The dried sample is then treated by Fischer Assay to determine the oil yield potential and to evaluate the loss in organic matter that is dissolved through the extraction process (Annual Report 2006, 2007).

\section{Environmental assessment studies}

The production, conversion, transport and final use of all forms of energy have certain environmental impacts. In the production of syncrude and the generation of electricity based on thermal decomposition, gasification and direct combustion of oil shale, hot gases are normally discharged, containing constituents. Prior to the commencement of any oil shale operation, environment impact assessment (EIA) should be conducted to develop data covering all environmental areas. The key areas to be addressed are described below.

The following environmental impact is expected to occur as a result of oil shale utilization, either through mining, handling, crushing or processing. Among these expected issues are overburden, atmospheric emissions (gases and dust), water contamination, solid and liquid waste (such as rejected material, spent shale), potentially hazardous health effects, changing natural landscape and topography, potential vibration and noise, and destruction of natural vegetation cover. In this case the EIA could play a very important role in providing the best measures that lead to eliminating (or reducing to a minimum) such potential impact, both on humans and the environment. 


\section{Water pollution}

There is a need for the development of protective measures for both surface and ground water supplies, and for measures to mitigate surface and ground water contamination due to mining and ash disposal. Excavation of ditches around the pit area and the out-of-pit waste pile are measures to prevent rain water run-off from becoming contaminated. Rain water run-off will be collected in sedimentation ponds and will have zero discharge. This will prevent any contaminant from entering the ground water. Leachability tests of the spent shale ash are required as well as testing of the overburden for its chemical properties. Spent shale must leave the retorting operations through water-filled lock hoppers to ensure thorough saturation prior to being hauled back to mine reclamation site. The elution test of some ash samples showed that some traces of heavy metals of environmental concern were found. Successive analyses have also shown that ground and percolating waters are highly alkaline and saturated with gypsum after contact with the ash. As a mitigation measure, ash must be layered with the overburden in the disposal plan in order to minimize wind erosion and to reduce the potential of leaching (Abu-Hamatteh et al. 2008).

\section{Atmospheric air emissions}

Air pollution from the mine area will be mostly dust. The operation will be equipped with water tankers and the pit road will be sprayed with water regularly. The noise level due to mine blasting is less significant since blasting the oil shale is not required. Dust collectors will be used to prevent air pollution at the process plant. The major pollutants arising from the processing of oil shale are smoke, $\mathrm{SO}_{\mathrm{x}}, \mathrm{NO}_{\mathrm{x}}, \mathrm{CO}, \mathrm{CO}_{2}$ and particulates. For particulates, typical preventive measures will be taken to prevent ash being emitted into the atmosphere. These measures include electrostatic precipitators and bag filters. They should be able to reduce the particulate matter emitted to less than $80 \mathrm{mg} / \mathrm{m}^{3}$ of flue gas and leads to a $12 \%$ reduction in carbon dioxide.

\section{Gaseous emissions}

Emission standards specify the maximum amount of a given pollutant, which can be released into the atmosphere. Previous oil shale studies in Jordan have used the World Bank Guidelines because of their ready availability in a usable form. All gaseous fuels produced in the process will first be treated to recover ammonia and will then be desulfurized, before being used for hydrogen manufacture. Desulfurization techniques will be used to remove the sulfur from the retorted gases. The hydrogen sulfide thus recovered and will be converted to valuable elemental sulfur. 
Sulfur dioxide $\left(\mathrm{SO}_{2}\right)$

Jordanian oil shale has a high alkaline ash content, requiring no limestone to be added for sulfur removal. The pilot test results indicate excellent sulfur capture by the calcium in the oil shale. In the combustion process most of the sulfur is oxidized to form $\mathrm{SO}_{2}$ and a small fraction is further oxidized to form $\mathrm{SO}_{3}$. The following reactions take place during combustion:

Step 1: Limestone $\left(\mathrm{CaCO}_{3}\right)+$ Heat $=$ Calcium oxide $(\mathrm{CaO})+$ Carbon dioxide $\left(\mathrm{CO}_{2}\right)$

Step 2: Calcium oxide $(\mathrm{CaO})+$ Sulfur dioxide $\left(\mathrm{SO}_{2}+1 / 2 \mathrm{O}_{2}\right)=$ Calcium sulfate $\left(\mathrm{CaSO}_{4}\right)$ like plaster. In the circulating fluid bed boiler, oil shale is mixed with limestone and suspended in a powerful air flow. Inside the boiler, the mixture is heated up and changes to lime that captures sulfur dioxide and forms calcium sulfate known as gypsum.

\section{Nitrogen oxides $\left(\mathrm{NO}_{x}\right)$}

The two most important nitrogen oxide air pollutants are nitric oxide (NO) and nitrous oxide $\left(\mathrm{NO}_{2}\right)$. Both are produced in the combustion process arising from the high temperature reaction between $\mathrm{N}_{2}$ and $\mathrm{O}_{2}$ in the combustion air, and from the oxidation of organically-bound nitrogen in certain fuels. The $\mathrm{NO}_{\mathrm{x}}$ emission levels increase with increasing temperature. The pilot test results indicate acceptable $\mathrm{NO}_{\mathrm{x}}$ emissions. The low $\mathrm{NO}_{\mathrm{x}}$ emission is brought about by the low combustion temperature of only $800^{\circ} \mathrm{C}$. The $\mathrm{NO}_{\mathrm{x}}$ emission levels increase with increasing furnace temperature. Mining the material, like any open mining, poses an environmental threat by dredging up heavy metals and unwanted substances better left underground. Having the extraction plant near the mine would allow returning the by-products into the mine pits, as well as reduce transportation costs. This must be done carefully, however, as the waste is a health concern. Furthermore, large quantities of water are needed for the extraction, a resource that is becoming as precious as oil itself.

\section{Prospects for ash utilization}

A limestone and clay mixture is the most important raw material for the production of cement. The mixture is pulverized and subsequently fired in a rotary furnace to turn into cement clinkers. The cement industry began using oil shale to improve the quality and economics of cement production. Research has drawn attention to the fact that the large quantity of high calcium ash of Jordanian oil shale is suitable for a wide range of utilization such as cement production, construction of roads and manufacturing of bricks and tiles. Cement is made from a mixture of raw materials which mainly contains calcium oxide, silicon dioxide, aluminum oxide and iron in specific proportions. 
Preliminary R\&D concludes that the high-calcium ash of Jordanian oil shale is suitable for a wide range of utilizations (Abu-Hamatteh et al. 2008) such as:

- Construction material including bricks, tiles, lightweight aggregate cement mixing for manufacturing of concrete products,

- Construction of road bases, use filler in asphalt mixtures,

- Stabilization of soils conditioner and fertilizer production (liming of acid soils),

- Production of foundry cores,

- Supplement in animal food.

Studies conducted by Bechtel National (1989) concluded that shale ash binding matter does not correspond to the standard requirements for Portland cements with respect to the regularity of volume variation during the first week of hardening. Moreover, a sample of shale ash from the combustion test was studied chemically and physically, with the following results:

- The tested oil shale ash has shown good ability for grinding, which assists in increasing the earlier strengthening for cement,

- Tests proved that the cement containing some amount of ash became stronger after 3-7 days,

- When the ratio of ash mixed with cement exceeds $20 \%$, some negative impact appeared due to the high content of $\mathrm{P}_{2} \mathrm{O}_{5}$ in the ash.

Several studies were conducted (Mustafa et al. 1993; Katamine 2000) to examine all factors and components such as mechanical properties, high strength, permeability and self-binding properties. They have drawn attention to the fact that the large quantities of high calcium ash of the Jordanian oil shale is a suitable and cheap material for the production of a wide range of valuable materials such as fertilizer, soil conditioner, and construction material (cement manufacturing and industrial products such as adhesives, varnishes, pesticides, benzene and urea resins).

The energy released when oil shale is burnt is used to generate electricity or heat; the ash produced is ground with cement clinker to provide oil shale cement characterized as a binding material. The basic materials which are normally blended to form cement, such as limestone, clay, fluorite, and iron oxide, are already present in the oil shale ash. The chemical composition of Jordanian oil shale ash indicates that almost $87 \%$ of cement raw materials exist in oil shale, represented by calcium oxide, silicon dioxide, aluminum oxide, and iron $(48,29$, 7 and $3 \mathrm{wt} \%$, respectively).

Germany and China have used oil shale as a source of cement (Dehong and Jialin 1991). By grinding 70 parts of Portland cement clinker together with 30 parts of oil shale combustion residues, the so-called oil shale cement is produced in Dotternhausen, which hardens quickly and has pozzolantic properties. It has the same properties as normal Portland cement and the hydration heat of this type of cement is low. More than 300,000 tons of oil shale cements are produced annually while the power station generates $84000 \mathrm{MWh}$ annually. Deutsche Babcock cooperates closely with Portland Zementwerk Dotternhausen Rudolf 
Rohrbach, where two fluidized bed-fired power station units have been operating for a number of years, each generating $3 \mathrm{MW}$ by oil shale combustion to provide power for the cement works, making it less dependent on the public grid. The combustion residues are delivered to the cement works where they are ground together with cement clinker. In this way oil shale has a dual function as a source of energy and raw material for cement production (Dehong and Jialin 1991).

Jordan Cement Factories Company is independently working on an experiment to use shale oil as fuel in the industry; the following are the main results of the experiment:

1. Oil shale ash can be utilized in the manufacturing of cement clinkers. It not only provides the energy source for the clinkering reactions, but the oil shale ash, which is normally of high proportion, can also be used as the clinker raw material.

2. Up to $15 \%$ of oil shale ash can be used with a typical Portland cement clinker without affecting the main properties of the cement. The addition of oil shale will reduce the required temperature to around $1300{ }^{\circ} \mathrm{C}$ instead of the typical $1450-1500{ }^{\circ} \mathrm{C}$. At this temperature, the clinker will have enough liquid phases to undergo the clinkering reactions.

3. A blending ratio of $22 \%$ oil shale ash, $25 \%$ kaolinite and $53 \%$ calcite is suggested by this study to maximize the benefits of utilizing the Jordanian oil shale. A corresponding temperature of $1300-1350{ }^{\circ} \mathrm{C}$ is also suggested for that blending ratio.

\section{Conclusion}

At the current price level of conventional crude oil of $\$ 60 / \mathrm{bbl}$, producing oil from shale becomes economically viable. With this technological improvement Jordan will be able to become self-sufficient in oil production, consumption and exporting. The GOJ has taken essential measures to encourage foreign investments in oil shale processing and utilization. The new investment law and the new electricity law will provide equal opportunities to enable developers to establish privately-owned oil shale projects.

Due to the importance of oil shale to Jordan as the only major proven indigenous energy source, extensive studies were carried out with the objective to assess the quality and the quantity of the oil shale and the suitability of using it as a reliable energy source. The studies have indicated that Jordan possesses a large quantity of oil shale of good quality. All tests have proven environmental, technical and economic feasibility and the studies have recommended that pilot demonstration plants should be constructed prior to embarking upon any commercial-scale project. Once clear indications are in hand that major firms are ready to invest in scaling up and demonstrating oil shale technologies, government attention should be directed at gathering long lead-time information required to support future oil shale utilization. R\&D carried out worldwide, combined with ongoing operations and recent testing abroad, 
supports the judgment that mining and surface retorting is a technically viable approach for producing strategically significant amounts of oil.

Oil shale utilization for power generation and retorting should be pursued because it will result in significant energy supply security and savings in foreign exchange, and also create new jobs. The oil shale in Jordan is considered, according to international standards, as the highest-grade oil shale available at shallow burial depth near existing infrastructure needed for an oil shale industry. It is appropriate to begin the demonstration stage once basic uncertainties have been resolved and the new information gained indicates that the demonstration will generate information about other remaining uncertainties associated with a much larger-scale effort.

There is a clear economic interest for Jordan to have oil shale utilization developed as a strategic energy source. In the medium and long-term, oil shale will dominate the world's energy supply system. Oil shale is seen as a viable option at today's oil prices, so that oil shale utilization will result in significant savings in foreign exchange, improve Jordan's energy supply and security and create new jobs. Jordan is developing competition for access to its oil shale resources and has encouraged private sector involvement in this field, so that at this stage the nation is well placed in terms of implementing its strategy.

The time seems right to recognize and pursue the potential of Jordan's oil shale and to include oil shale in the mix of energy resources, policies, and programs to sustain Jordan's economic growth and vitality and bolster national energy security. After discovering the vast reserves, Jordan has become one of the most attractive investment and operational acreage holders in regards to oil shale development.

The sharp rise of crude oil prices in the international markets will improve the economics of investment in the field of shale oil. Jordan is currently licensing a small portion of its oil shale resources and is expected to award more once the extent of resources is determined and the interest and capabilities of companies are verified. The current oil shale policy will lead to a multi-purpose process (consisting of electricity generation, thermal retorting, cement production as well as mineral extraction) that could achieve high utilization factors for both the oil shale's chemical and energy potentials.

\section{References}

Abu Ajamieh, M. 1980: An assessment of the El-Lajjun Oil Shale Deposit. - Internal Report, Natural Resources Authority, Amman-Jordan.

Abu-Hamatteh, Z.S.H., J.O. Jaber, M.S. Besieso, S.A. Al-Jufout, T.A. Al-Azab, A.F. Al-Shawabkeh 2008 Jordanian Oil Shale: A Promising Strategic Source of Energy. - In: White, J.R., W.H. Robinson (Eds): Natural Resources: Economics, Management and Policy. New York, Nova Science Publishers, Inc., Chapter 3, pp. 89-129.

Annual Report 2006: Energy, Facts and Figures. - Ministry of Energy and Mineral Resources, Amman, Jordan.

Allred, V.D. 1982: Oil Shale Retorting Phenomenology. - In: Allred, V.D. (Ed.): Oil Shale Processing Technology, The Center for Professional Advancement. New Jersey, US, pp. 67-81. 
Altun, N.E. 2006: Oil shales in the world and Turkey; reserves, current situation and future prospects: a review. - Oil Shale, 23/3, pp. 211-227.

Annual Report 2007: Mineral Status and Future Opportunity: Oil Shale. - Natural Resources Authority. Amman, Jordan.

Bechtel National Inc. and Jordan Electricity Authority 1989: Pre-feasibility Study: Oil Shale Utilization for Power Production in the Hashemite Kingdom of Jordan, Contract No., LAC5724-C-5126-000. - Amman, Jordan.

Bender, F. 1974: Geology of Jordan. - Gebrueder Borntraeger, Berlin, 196 p.

Bender, F. 1968: Geological map of Jordan, Amman sheet, scale 1:250000. - Supplement edition in English with minor revisions.

Brown Boveri \& Company Ltd. and Jordan Electricity Authority 1987: Pre-feasibility Study for a Power Generation Plant Using Jordanian Oil Shale. - Jordan Electricity Authority, Amman, Jordan.

China Petro-Chemical International Company and Natural Resources Authority 1986: Evaluation of Suitability of Processing El-Lajjun Oil Shale in a Single Fushun Type Retort. - Natural Resources Authority, Amman, Jordan.

Combustion Engineering Lummus Canada Inc. and Jordan Electricity Authority 1988: Feasibility Study for Direct Combustion of Jordanian Oil Shale for Electricity Generation. - Jordan Electricity Authority, Amman, Jordan.

Dehong, P., Q. Jialin 1991: Oil Shale Activities in China. - Oil Shale, 8/2, pp. 97-105.

Dinneen, G. 1970: Evaluation of the Investigation of the Oil Shale Resources of Jordan and Comments on Their Utilization. - U.S. Bureau of Mines.

Harada, K. 1991: Research and Development of Oil Shale in Japan. - Fuel, 70, pp. 1330-1341.

Jaber, J.O., M. Mohsen, M. Amr 2001: Where to with Jordanian oil shales. - Oil Shale, Estonian Science Academy Journal, 18, pp. 401-421.

Jaber, J.O., S.D. Probert 1997: Exploitation of Jordanian Oil Shales. - Applied Energy, 58, pp. 161-175.

Katamine, N.M. 2000: Physical and Mechanical Properties of Bituminous Mixtures Containing Oil Sales. - Journal of Transportation Engineering, 126, pp. 178-184.

Lurgi GmbH 1988: Oil Shale Retorting by the Lurgi-Ruhrgas (LR) Process. - Document No. 1560e/2.88, Frankfurt am Main, Germany.

Lurgi and Klockner, L. 1986: Full Fledged feasibility study for 50.000 BBL/D. Retorting complex ElLajjun. - Phase I: Executive Summary, Natural Resources Authority, Amman-Jordan.

Lurgi GmbH and Natural Resources Authority 1986: Technical and Economic Feasibility of a LargeScale Oil Shale Retorting Complex. - Natural Resources Authority, Amman, Jordan.

Mitsubishi Heavy Industries Ltd and Natural Resources Authority 1986: Preliminary Characterization Test of a Typical El-Lajjun Oil Shale. - Natural Resources Authority, Amman, Jordan.

Mustafa, I., M. Bsieso, W. Bakri, Z. Jebril, F. Anani 1993: Renewable Energy in Jordan: Share in Total Energy-Mix. - The Higher Council for Science and Technology, Amman, Jordan.

National Electric Power Company (NEPCO) 2007: http://www.nepco.com.jo/Jordan.

Ots, A. 2007: Estonian oil shale properties and utilization in power plants. - Energetika, 53/2, pp. 8-18.

Powell, T.G., P.J. Cook, D.M. McKirdy 1975: Phosphorites: relevance to petroleum genesis. - AAPG Bulletin, 59, pp. 618-632.

Quennell, A. 1951: The geology and mineral resources of (former) Trans-Jordan Colonial. - Geol. Miner. Resour. London, 2, pp. 85-115.

Speers, G.C. 1969: El-Lajjun Oil Shale Deposit, Jordan. - Report No. EPR/R 7005, British Petroleum Company, London, UK.

Speight, J.G. 1990: Fuel Science and Technology Handbook. - Marcel Dekker, Inc., New York, USA.

SUNCOR Energy Inc. 1999: Presentation about Jordanian Oil Shale Project: Conceptual Design. Amman, Jordan.

Taciuk Processor 1987: 4th Australian Workshop on Oil Shale, 3-4 December. - University of Queensland, Australia.

Tissot, B.P., D.H. Welte 1978: Petroleum Formation and Occurrence. - Springer-Verlag, New York. 